\title{
From Local Conflicts to Global Terrorism: Can Refugees and Regional Security Problems Jeopardise the Renewal of Kenya?
}

\section{Babere Kerata Chacha*}

\begin{abstract}
Over the last decade or so the African continent has continued to experience political changes of monumental proportions. Monumental not only because of the drastic restructuring of social and economic and political spaces, but also because of the introduction of new forms of politics and political actors. These changes were driven a great deal by the developments in the global system, in particular, the demise of the Soviet Union as a nation and super power, the triumph of the market, and more importantly, the end of the Cold War. In relation to these changes, the African continent has equally been characterised by a succession of large-scale refugee movements, internal population displacements and mass repatriation movements. In a number of countries Angola, Burundi, Liberia, the Democratic Republic of the Congo (DRC), Rwanda, Sierra Leone and Somalia, for example, large proportions of the population have been uprooted, forced to abandon their homes by communal and ethnic conflict, persecution and violence. Most of these refugees have ended up in Kenya with a number of arms or religious fundamental ideologies. The process has witnessed an influx of arms in Kenya, helping fuel intra-ethnic and inter-border conflicts. Kenya has witnessed massive devastating terrorist attacks beginning with the bombings of the US Embassy and now Kenya has become an easy prey and target for terrorist activities. The reasons for this trend have been a concern for academics around the globe. A close look at intra-state conflicts in East Africa reveals a common pattern, for example: rebellion against central authority; inter-communal ethnic or religious conflicts; sporadic short lived conflicts related to resource around livestock; and generalised violence which is banditry-related. This study is a historical investigation of the development of
\end{abstract}

\footnotetext{
* Department of History, Egerton University, Njoro, Kenya.
} 
local conflicts, informal militia and security measures during the transition to political pluralism in Kenya between 1992-2002, and tries to establish some links that may have connected or caused the country to be a target of international terrorism.

\section{Résumé}

Au cours de la décennie passée, le continent africain a vécu d'autres changements politiques aux proportions monumentales, non seulement du fait de la restructuration radicale des espaces sociaux et politiques, mais également du fait de l'introduction de nouvelles formes de politiques et d'acteurs politiques. Ces changements ont pour la plupart été provoqués par les développements intervenus au niveau du système mondial, en particulier la chute de l'Union Soviétique en tant que nation et superpuissance, le triomphe de l'idéologie de marché, et surtout, la fin de la Guerre Froide. Avec l'intervention de tous ces changements, le continent africain a également connu une succession de mouvements de réfugiés à grande échelle, ainsi que des déplacements internes de population et des mouvements de rapatriement de masse. Dans un certain nombre de pays - Angola, Burundi, Liberia, République Démocratique du Congo (RDC), Rwanda, Sierra Leone et Somalie - par exemple, une grande partie de la population a été déracinée, forcée d'abandonner foyers et maisons du fait de conflits communautaires et ethniques, et de la persécution ou de la violence dont elle fait l'objet. La plupart de ces réfugiés s'est retrouvée au Kenya en détention d'un certain nombre d'armes ou entretenant des idéologies religieuses fondamentalistes. Ce processus a engendré un influx d'armes au Kenya, attisant ainsi les conflits intra ethniques et inter frontaliers. Le Kenya a connu des attaques terroristes de masse à l'impact dévastateur, qui ont débuté avec les attentats contre l'Ambassade Américaine, et ce pays est à présent devenu une proie et une cible faciles pour les activités terroristes. Les origines d'une telle situation constituent une réelle préoccupation pour la communauté académique mondiale. En examinant de plus près les conflits intra-étatiques en Afrique de l'Est, on note une constante: le phénomène de rébellion contre une autorité centrale; les conflits intercommunautaires ethniques ou religieux; les conflits sporadiques de courte durée, liés au contrôle du cheptel ; et enfin, la violence généralisée liée au banditisme. Cette étude constitue une enquête historique sur le développement des conflits locaux, des milices informelles et des mesures de sécurité adoptées durant la période de transition vers le pluralisme politique au Kenya, de 1992 à 2002. Cette analyse tente d'établir des liens qui auraient amené ce pays à devenir une cible du terrorisme international.

\section{Introduction}

In contrast to many of its neighbours, Kenya is often seen as a bastion of stability. The country has several strengths that militate against the outbreak of mass violence, but it also exhibits many of the factors that have been markers of civil strife elsewhere in Africa: strong ethnic divisions, polarised political issues, political manipulation, rampant vio- 
lence, socio-economic disparities, a lack of economic opportunity, and endemic corruption. When combined with the increased availability of firearms, this dangerous mix becomes all the more volatile. The easy availability of such weapons within the country contributes to the growing culture of violence that is taking root inside Kenya. In addition to rising crime and generalised insecurity in recent years, the country has experienced repeated flashes of politically inspired ethnic violence, especially during election periods. Those instigating this deadly violence have not been held to account. This continuing pattern of violence and impunity, together with the spread of small arms, threatens Kenyan society and greatly endangers human rights.

The region has suffered from all these types of conflicts for a long period. While at the local level, Kenya is today leading in sporadic violent banditry, which includes car jacking, bank and house robberies, and murders. The focus of this research is to explore whether there is any inter-linkages between and within these conflicts. To start with, it is very clear that as far as cattle rustling is concerned, this is a phenomenon that cuts across ethnic lines and national borders. The illegal circulation of small arms has created a strong inter-linkage of conflicts in the region. Arms once used for cattle rustling have become available for car-jacking, highway and bank robberies.

Coming to rebellion against the state, there is a strong thread linking up the countries of the region. The conflict in the Sudan is perhaps the classic example, and there have been inter-linkages since the flare up of the present conflicts. Most of the local authorities and the region as a whole are under the control of Islamic fundamentalists. In all these conflicts there is an Islamic factor, which links the Oromos, the Somalis and the Kenya Somalis and the Sudan.

Arms, people and fundamentalist ideologies are moving freely within a conflict system. Whenever a major conflict is resolved, a large surplus of arms often becomes available to others involved in conflict. With such a picture it is important to approach the problem globally as a conflict system. This research seeks to address a major question that arises from this: What steps can be taken to begin to address the problem from a conflict system scenario? Furthermore, the regionalisation of domestic conflict that has come to characterise Africa in the past decade has affected Kenya as well. Armed conflict in neighbouring countries has destabilised Kenya through cross-border incursions and trade in small arms, often on the basis of kinship ties that traverse interna- 
tional frontiers. In addition, the situation in Kenya has had an impact, albeit less dramatic, on its neighbours.

\section{The Setting}

During the 1990s African states experienced failed economic programmes, the unequal distribution of the pains and costs of orthodox stabilisation and structural adjustment programmes, the delegitimisation of the violent neo-colonial state, frustration with existing institutions, and a new desire to end the decades of oppression, violence, intimidation, waste and corruption. These trends led people to demand national sovereignty, open elections, sharing of power, the overthrow of the old order, an end to military rule and patrimonial regimes, and constitutional reform. In addition and more particularly, in sub-Saharan Africa more than anywhere else, direct intervention from foreign aid donors has played an important role in several recent transitions to democracy. For example, in Malawi and Kenya, multilateral and bilateral donors specifically suspended new foreign aid in the early 1990s until political reform was enacted - a practice known as political conditionality. As a direct result, in both cases, authoritarian rulers held multiparty elections. In Kenya a severely flawed electoral process returned the same regime to power.

Equally, the demand for the (re)introduction of democratic institutions into the African political space during the 1990s resulted in several processes. In some countries multiparty elections witnessed changes in government. These included countries like Benin, South Africa, Zambia, Mali, Niger, Congo, Madagascar, Central African Republic, Lesotho, and Malawi. In other cases, multiparty elections resulted in no change in government. These included Ivory Coast, Zimbabwe, Namibia, Mozambique, Guinea Bissau, the Seychelles, Ghana, Burkina Faso, Kenya, Guinea-Conakry, Comoros, Mauritania, Cameroon, Gabon and Togo (Olukoshi 1998).

However, one common feature in all these cases was unprecedented and widespread violence, meted out to either the ruling party sympathisers or to those sympathetic to the opposition. In countries like Kenya and Malawi where the ruling regimes had anticipated violence with the introduction of multiparty politics, opposition leaders were often targeted together with their supporters (Murunga 1999).

In his speech, delivered at the annual general meeting of the Freedom of Expression Institute, Johannesburg (1996), Chifu Ayakub explained 
that 'the process of democratisation which we have witnessed in many African countries over the past six or seven years has, on occasions, brought with it an unwelcome concomitant. Many of the "new democracies" have found themselves almost immediately plunged into political violence, formation of informal militia and sometimes but not always with an ethnic tinge: Kenya, Rwanda, Burundi, Cameroon and others'.

Ironically, some African leaders, such as Daniel Arap Moi of Kenya, used this descent into violence as evidence of the inherent tribalism of Africans and thus of their unsuitability for multiparty democracy. This is, almost word for word, an echo of the old idea of the 'white man's burden'. The role of European colonialism - or these days the postcolonial state - was to keep 'natives', with their primordial tribal divisions, from hacking each other to pieces.

Therefore, the transitions to pluralist politics in many parts of Africa were marked by violence, intimidation and harassment by either those holding political power and those seeking it. The political space became an arena where informal militia groups developed either to cushion the older regimes or those seeking change. Yet, despite the similarities, we lack a detailed comparative historical study of this phenomenon, particularly, how these developments interlinked with ethnic conflicts in neighbouring communities. In addition, further compounding these disturbing trends have been the stream of refugees fleeing upheavals, and the incursion of international terrorism.

\section{Kenya-US Relations: A Cause for the Terrorist Target?}

Although the United States and Kenya have enjoyed cordial relations since Kenyan independence, these relations have in one way or another contributed to the terrorist aggression in Kenya. The Kenya-US relation needs consideration, since for one, more than 7,000 US citizens live in Kenya, and as many as 25,000 Americans visit Kenya annually. About two-thirds of the resident Americans are missionaries and their families. US business investment is estimated to be more than $\$ 285$ million, primarily in commerce, light manufacturing, and the tourism industry. President Moi was a close ally of the West in general and it is clear that American and Israeli intelligence agencies always enjoyed a strong presence in Kenya. 
Moi's support was important for the United States during the Cold War when it set about destabilising the progressive regimes in the region. The strong-arm methods Moi used against his opponents after a failed coup in 1982 did not bother the West. Today Kenya plays a crucial role in the US game plan for West Asia. American troops were given base facilities and logistical support as the US prepared for war against Iraq.

The United States has spent \$3.1 million (Sh210 million) on antiterrorist training in Kenya since 1998. However, its recent travel advisories to their nationals not to visit Kenya because of the threat of terrorist attacks are, in the opinion of many economists, undermining the new government's project of economic and political renewal. The US presence, therefore, may shape the nature and source of terrorism in Kenya. The US believed that supporters of al-Ittihad al-Islami, which it identifies as 'a Somali terrorist organisation with links to al-Qaeda', (East African Standard 16/09/03, p.6.) have infiltrated some of the refugee camps in North-Eastern province, and made their way to Mombasa and Eastleigh, the Nairobi quarters of Somalis. Furthermore, it is alleged that 'they may well have gained support among the thousands of unemployed youths, hit by the decline of the tourism industry'(Kenya Times, 27/1/03, p.18). While in both the 1998 bombing and the attack on the Israeli hotel some Kenyans were implicated, a point which outgoing ambassador Johnnie Carson has not tired of repeating, the feeling seems to be that Islam is not a major factor.

When the US prepared to go to war in the Persian Gulf, the then President Daniel Arap Moi confirmed its right to use the Mombasa port as a supply and recreational base, and to airlift men and materiel to the Gulf through the Nanyuki military airbase. If the country did not maintain these facilities and old strategic links with the US, Washington would certainly be less concerned about the terrorist threats it was facing. In that sense Kenya's blessing is also its curse.

This role, according to the survey, goes beyond the single issue of counter-terrorism. For more than a decade, Operation Lifeline Sudan has been a vital conduit of humanitarian relief to southern Sudan from its base in Turkana District. Kenya also provides a haven to thousands of Somali refugees. In his last year in office, President Moi played an important role in efforts to end the civil war in Sudan, building on the peace initiatives of former US Senator John Danforth. This initiative led to the Machakos protocol on the issue of self-determination for southern Sudan. 
Since the US continues to regard Kenya as one of the four 'anchor states' in sub-Saharan Africa, and has heightened concerns over the penetration by Al-Qaeda, how does one make sense of Kenya's present position? One possible conclusion is that the 'weakening of the country's counter-terrorism' institutions happened because of the decay and politicisation of the security apparatus during the rule of KANU. Action needs to be taken now while the reform momentum is high. This would explain the timing of the pressure on the Government to deal with terrorism. Raising the scare level and raising the price of inactivity on terrorism is likely to create a lot more local acceptance for the actions necessary to deal with the threat.

The alarm bells from the US that ring in Kenya over terrorism would be equally important in winning domestic support for anti-terrorism security assistance to be funnelled to Kenya. According to Strategic Survey, US actions in Kenya 'mean Washington will have a standing, if secondary, interest in strengthening Kenyan institutions and in "inoculating" its Muslim population against radicalisation through longer-term development programmes'.

\section{Regional Insecurity and Terrorism: The Role of Neighbouring Countries}

The absence of a responsible government, administrative apparatus, organised politics and government or private business in Somalia, became a haven for the fundamentalists to fill the vacuum and gave them a comparative advantage over the other forces who lacked any kind of ideology. Although traditionally clan loyalty is more important than any religious affiliation in Somalia, war weariness, desperation, eagerness for peace and order as well as widespread poverty seem to have attracted the youth to join the fundamentalist camp. That is why Islamists in Somalia target the youth more than any other group for terrorist activities. Undoubtedly Islam preaches peace and harmony, but Islamic extremists in Somalia tend to use political Islam as a weapon for the elimination of enemies and peace forces in the area. In fact, my fear is that Islamic extremists are trying to destroy the long-standing tolerance and harmony among Muslims and Christians in the horn of Africa (Tadesse 2001)

Fighting in Ethiopia in many cases spilled over into Kenya. Ethiopian security forces have crossed the border and attacked the Borana 
people, who are believed to support the Oromo Liberation Front (OLF), which is fighting for greater autonomy from the Ethiopian government. Members of the OLF are reported to have placed landmines in Kenyan territory and attacked local ethnic Somalis. Over 25,000 people were reported displaced in December 2000, after militiamen from Ethiopia crossed into Kenya's Wajir District. ${ }^{1}$ The Turkana are targeted as well. For instance, in September 2002, Ethiopian raiders killed 16 Kenyans in Turkana District (Daily Nation, 18 September 2002).

Militias from Somalia have also entered Kenya, attacking Somali refugees and Kenyan ethnic Somalis, effectively rendering the border area unsafe. General Mohamed Farah Aidid's forces, for example, carried out a number of raids in retaliation for the Kenyan government's support of his rival Mohamed Hirsi 'Morgan', who has important links to ethnic Somali clans in Kenya (Africa Confidential, 9 November 2001). The Sudanese government has used allied local warriors in Southern Sudan to attack the Turkana in Kenya on the pretext of cattle-rustling. ${ }^{2}$ Far worse and more widespread geographically has been the influx of small arms into northern Kenya.

\section{Religious Backlash and the Arab Silence}

Curiously, some scholars blame Arab aggression and are wondering why Africa must bear the brunt of a Middle East conflict. The continent is not an enabler, nor is it a global power to force mediation on the combatants. So why this carnage on her soil? That question has been answered by individual Africans who interpret the attacks as the result of sheer arrogance and contempt for African lives. On being told about the latest bomb blast, Vice-President Musalia Mudavadi of Kenya said to the BBC that 'his country has become a battleground for other people's wars and is being dragged into issues over which it has very little influence'. This perspicacious remark is however limited because it does not mean that the whole African continent is under attack. However, among Africans in North America, there are rumblings about Arab insensitivity to Africans.

They are struggling to understand why Arabs enjoy abundant hospitality in Africa, even to the point of being allowed to expropriate key sectors of the continent's economies; yet pay Africa back with ingratitude. There was a time when it was easy for Africans to sympathise with Middle Eastern problems. Many saw the problems through the 
prism of religion and not from the point of self-interest. But with these attacks, religion in politics, especially the Islamic brand in certain parts of Africa today, is coming under scrutiny. A reader, observing the increasing Islamic hold on governance in some states of Nigeria, wrote with concern to state that "There is a new dictatorship abroad in Africa and it is called Islamic Fundamentalism'. ${ }^{3}$ And connected to Islam in many eyes in Africa is the Arab brand of nationalism.

According to George Ayittey, professor of economics and a leading Africanist, who spoke recently on the Jim Lehrer Report, there have been 'invaders, colonizers and slavers, who used their religions - Christianity and Islam, neither of which is indigenous to Africa - to convert, oppress, exploit and enslave blacks'. He said that 'While the Europeans organized the West African slave trade, the Arabs managed the East African and trans-Saharan counterparts... Over 20 million black slaves were shipped from East Africa to Arabia'. Should the history of the slave trade, and current events in Sudan and Mauritania be enough to turn Arabs into enemies in Africa? Not yet. One reader, upon learning of the atrocity in Kenya, also wrote to complain: 'Would the African Union condemn this? NO! Because it has not been perpetrated by the West'. ${ }^{4}$

The implication of this statement was that had terrorist attacks been the work of the West, African leaders would be lining up to condemn them vociferously. No Arab country has condemned the Nairobi and Tanzania bombings since 1998. Dr. Ayittey finds in this silence a message that is 'particularly arrogant and maddening'(Ablorh-Odjidja 2002). Is this reticence on the part of African leadership caused by fear of a religious backlash? If so then the future will be very horrifying for Africa.

\section{Refugees and Terrorism}

It is not the intention of this article to enter into a lengthy discussion on the concept of security. This concept, over the last decade, has been the focus of intense academic debate. Much of the debate has revolved around the central issue of just what is supposed to be protected. The ensuing debate has challenged one of the central assumptions of realist thought that holds that the protection of the state, its borders, resources, population and so on, is the essence of security. Security was provided primarily through military force, backed by a robust economy and stable political leadership. During the Cold War, the linkage between military 
activity and security became so strong that an issue that did not involve military force was simply not a security issue (Baldwin 1997).

In the wake of the Cold War, the state-centric notion of security has been heavily challenged. ${ }^{5}$ Among the alternatives to military dominated, state-centric concepts of security are: societal security (Buzan \& Wilde 1998), individual, or human, security (Booth 1991), and international security. ${ }^{6}$ As they apply to the situation of refugees in the Great Lakes region, each of these concepts, as well as the more traditional notion of state-centric security, will be examined. The very concept of societal security is also problematic, and contains some troubling nuances. Societal security is a state-centric notion. Not only must the state ensure the security of territory, resources and population, but also of 'identity'. Identity includes such components as language, culture, religious customs and so on. Refugee flows thus could be a threat to societal security (Katzenstein 1998).

Examining threats to state security involves looking at threats to territorial integrity, political autonomy, internal stability, and economic well-being. Throughout all phases of the conflict, the presence of large numbers of refugees, to varying degrees, constituted threats to the state security of all of the countries in the region. Opponents of the concept of societal security find much to criticise. Some claim that the identification of refugees as a societal threat may imperil their human security (Goodwin-Gill 1999). Finally, claims of societal security may simply be an easy way to mask xenophobia and racism (Schuster \& Solomos 1999).

As a result of such notions and although Kenya is a signatory to the international agreements on refugee protection, the country has no established national legal framework to handle refugee issues, including the management of their resettlement and integration in the country. Instead, the government has let the United Nations High Commission for Refugees be at the forefront of managing the bulk of refugee affairs in the country. With no programmes for their permanent resettlement and integration in Kenya, a majority of refugees in the country are confined to camps in geographically remote semi-arid areas such as Dadaab and Kakuma.

Refugees in urban areas such as Nairobi and Mombasa have more options than those in the camps, but their lack of a recognised legal status has left them subject to frequent harassment by Kenyan police. 
They are also often the targets of native resentment and political scapegoating in connection with the rise in urban crime and the proliferation of firearms trafficked across the country's borders. Tensions between local communities and refugees living in camps have occasionally turned violent, with fatalities on both sides. The threat of international terrorism has also recently affected Kenyan attitudes and policies towards refugees with Muslim backgrounds whose population has been increasing in the country.

The bombing attacks by suspected Al Qaeda operatives on the US embassy in 1998 and on an Israeli hotel and plane in 2002 have spurred increased scrutiny by Kenyan police of refugees from Somalia and visitors from the Middle East. Since September 1 1, 2001, increased security checks have led to long delays in the departure of thousands of Somali Bantu refugees previously approved for permanent resettlement in the United States (Kenya Times, 8/7/03). Like these refugees, many ordinary Kenyans seeking visas for study, vacation, or business in the US, the UK, and other countries have also faced additional requirements and longer waiting times. The Kenyan government is active in regional peace initiatives, seeking political resolutions for the ongoing conflicts in Sudan, Somalia, the Democratic Republic of Congo, and Burundi.

The success of such initiatives will help to allow more of the refugees a chance to return to their home countries. On the domestic front, however, repeated promises by Kenyan government leaders to enact comprehensive legislation on refugee rights have not been fulfilled. The latest proposals from Kenya's minister of home affairs include a plan to allow skilled refugees the right to live and work anywhere in the country (Okoth Kenya 2003).

\section{Regional Security and the Proliferation of Small Arms}

Arms transfer and trafficking are having a devastating impact on subSaharan Africa. The proliferation of Small Arms and Light Weapons (SALW) is no doubt a global phenomenon whose adverse effects are most visible in Africa. These weapons make conflict more deadly and crime easier, feeding cultures of retribution and downward spirals of violence around the world. Besides taking a heavy toll on human life, small arms undermine nations' development. The widespread abuse of 
weapons deprives developing countries of the skills and talents of the victims of small arms. Small arms are the preferred tools of violence in most internal wars, coups, militia and gang rampages, government oppression and human rights abuses. The arms are also commonly used in domestic and transnational crime (Brown 2003b: 15). In cultures of violence and gun-ownership, these weapons become symbols of power and pride, even objects of affection.

The regional illicit arms trade began in earnest in 1979 with Idi Amin's overthrow in Uganda, after which members of Kenya's Pokot community purchased weapons from their ethnic cousins across the border in Uganda (Brown 2003b: 25). The subsequent civil war and its remaining vestiges have further increased the flow of weapons from Uganda, as has the civil war in Southern Sudan. Continuing political instability in two other neighbouring countries - the implosion of the Somali state in 1991, as well as the Ethiopian civil war, which overthrew a military regime in 1991 - also flooded northern Kenya with small arms and ammunition. As many as 5,000 automatic rifles, for instance, are said to cross the border with Somalia each month, while an estimated 90-95 per cent of households in northern Kenya are armed (Muggah and Berman 2001: 10-11).

The easily available, low-price smuggled weapons, many of which have found their way to Nairobi and the southern part of Kenya, have greatly contributed to insecurity. Between 500,000 and 1,000,000 small arms are believed to currently be in circulation (Muggah and Berman 2001: 10). The inability of the government to crack down on the arms trade, in my opinion, led in some cases to Kenya becoming a stagingground in a wider international conflict. For instance according to Brown, explosives used in the bombing of the US embassy in Nairobi in 1998 and of an Israeli-owned hotel near Mombasa in 2002, as well as the surface-to-air rockets that shot down an Israeli passenger jet as it left Mombasa in 2002, are widely believe to have been smuggled into Kenya across its 'porous border' with Somalia by al-Qaida operatives or allied groups (Brown 2003b).

It is quite true that weapon smuggling should be blamed on the hundreds of thousands of foreign refugees on Kenyan soil. In 2000, Kenya provided leadership in hosting a regional conference on the proliferation of small arms in the Great Lakes and the Horn of Africa. A few scholars blamed the Kenyan president for government's responsibility for the use of Kenya as a transit point for arms being shipped 
onward to conflict zones in Kenya's 'economic hinterland', many of which were diverted to the local market. ${ }^{7}$ Thus, the domestic dimension cannot be detached from the regional context of cross-border linkages in conflict and the arms trade.

In Uganda, the Karamojong for many years relied on traditional weapons when engaging in cattle and clan warfare. By the late 1990s, there was an estimated 30,000-40,000 AK-47 rifles in the hands of the Karamojong. Ownership of such weapons conferred a political, social and economic status. Often, an AK-47 was part of the dowry. In Kenya for instance, small arms are prevalent in the North Rift Region with a significant percentage of the male population possessing illegal arms. A report by the Nairobi based Security Research and Information Centre entitled 'Profiling Small Arms and Insecurity in the North Rift Region of Kenya' estimates that there are about 127, 519 small arms in the region. It is the prevalence of insecurity in this region that has contributed to the gun culture. The communities, largely pastoralists, arm themselves in a bid to protect their livestock from aggressors (Brown 2003b: 20).

The proliferation of small arms across the globe leads to the more rapid spread of violence and magnifies the devastating effects of violence, contributing significantly in areas of armed conflict to human rights abuses and violations of international humanitarian law. In countries emerging from war, the widespread availability of guns contributes to high levels of crime and makes the transition to a lasting peace more difficult. In Kenya and other countries not at war, the ready availability of these weapons undermines security (including increased crime), erodes prospects for development, contributes to social disintegration, and makes the resort to violence more likely - and more deadly.

Kenya has been vulnerable to weapons trafficking because of its geographic location in a conflict-ridden region. The weapons circulating in Kenya originate from places as far away as China and the United States, but most of them passed through war zones in neighbouring countries before making their way to Kenya's illegal gun markets. For years Kenya's territory has been a conduit for weapons shipments destined to nearby areas of violent conflict, but more recently the spread of weapons has spilled back into Kenya itself. For the time being, guns in Kenya circulate on a small scale when compared to its war-torn neighbours. They are smuggled into the country a few at a time in a steady flow and 
sold by traders in secret markets, with some larger-scale illegal arms trafficking also reportedly taking place.

The impact of even relatively modest quantities of such weapons, however, is already being felt. The increasing availability of weapons in Kenya has helped fuel rising insecurity and, in some areas, the growing militarisation of society. Much media attention has focused on the prevalent use of sophisticated weapons in urban crime, particularly in Nairobi. Often, refugees living in Kenya are scapegoated as the source of these weapons. The proliferation of small arms is most serious along Kenya's northern and western borders, where pastoralist communities have ready access to AK-47s and other automatic rifles obtained from neighbouring countries.

The introduction and spread of such sophisticated weapons among these communities has intensified conflict and blurred the line between long-standing ethnic competition - traditionally manifested in cattle theft or rustling - and political violence. Guns are now widely used to carry out acts of banditry and cattle rustling in Kenya, and have been responsible for growing numbers of human casualties, including during armed confrontations that pit ethnic groups against each other. This grave insecurity, as rightly noted by a Kenyan civic leader, derives both from 'the influx of small arms' and 'careless utterances and incitement' by politicians. ${ }^{8}$

Equally, several of Africa's main foreign aid donors (the United States, the United Kingdom and France), along with the Soviet Union, also provided a vast supply of weaponry during the Cold War. This flow, though reduced, continues to this day, as private companies based in these countries and Russia, along with their licensees in developing countries, sell the arms that exacerbate insecurity in Kenya and its neighbors (Human Rights Watch 2002: 8). The political economy of the international - and not just regional - arms trade plays a role in the endurance and spread of violence in Kenya and the rest of Africa. Therefore, the international context and international actors shape in significant ways the events under consideration here. The next task is to weigh the importance of the various dimensions and consider their theoretical significance.

\section{Weak Governance Structures - KANU and NARC}

Both weak governance and corruption at the entry ports of the republic, including the Jomo Kenyatta International Airport, have been blamed 
for the illegal migrations into Kenya. Observers see it as part of a wider pattern of terrorist aggression in Kenya. The state's role in declining security goes far beyond a simple lack of capacity, more precisely a failure to secure national borders and prevent lawlessness. The Kenyan case underlines the need to critically examine state-society relations. When power is as concentrated as it is in the Kenyan presidency, as it is still in the NARC government, incumbents are loath to relinquish it voluntarily. In no region is this more the case than in Africa. Thus, continued attention to domestic factors, especially the state, is warranted, taking into account the logic of neo-patrimonialism and the complexity of state-society relations. In integrating non-traditional actors into theorising, it is important not to forget that states can in many cases remain key actors.

There is a regional dimension to Kenya's declining human security that is of fundamental significance to the influx of terrorists into the region, as well as black-market regional trade, cross-border fighting, ethnic links that predate and cross colonial-era borders, ethno-regional identities that compete with national ones, and private armies, as well as incomplete sovereignty over large swaths of territory. The violence of the borderlands and the influx of small arms are closely linked to conflicts in neighbouring countries. Still, the regional dimension is less central in this case than the domestic and international ones. Though the availability of weapons and the lack of border controls have exacerbated human insecurity, especially in northern Kenya and cases of petty crime across the country, they were not a necessary precondition for organised violence.

Kenya's leadership role in regional organisations, especially in the areas of arms control and conflict resolution, provides it with the potential for improving human security throughout the region. However, as we have seen, domestic financial and partisan considerations have so far outweighed the benefits of greater regional stability.

\section{Socio-Economic Effects of Terrorism}

International tourism is one of the world's largest industries and many small, open economies such as Kenya heavily rely on tourism as a major source of foreign exchange earnings. In addition to its direct benefits, such as foreign exchange earnings, tourism is also a source of foreign direct investment (FDI) in many developing countries. Terrorism can hurt the tourist sector by reducing tourist arrivals. Over time, continued 
terrorist attacks may also reduce FDI significantly. Besides such direct short- and long-term costs, indirect costs of terrorism include the need for greater advertising expenses to attract new or more tourists, reconstruction costs for damaged tourist facilities, and security enforcement expenses to lessen terrorist threats. ${ }^{9}$

Major airports in Europe and Mediterranean have been forced to make costly improvements in security in response to growing terrorist attacks ( Drakos \& Kutan 2001). Most insurance companies now exclude coverage for losses suffered through terrorist-related injuries or losses, passing the cost of terrorism directly onto tourists and the owners of tourist facilities. Terrorism is more likely to have detrimental effects on tourist arrivals in countries with significant terrorist incidents.

To help in understanding the cost of terrorism in Kenya I also examine some selected countries in the Mediterranean region that have a high incidence of terrorism. For example, Turkey has been facing threats from several terrorist organisations, including the Islamic Great Eastern Raiders/Front, Kurdistan Worker's Party (PKK), and Turkish Workers' and Peasants' Liberation Army (TIKKO). Periodic bomb attacks and shootings by the PKK, especially in Turkey during the 1990s, have had a negative effect on tourist arrivals. According to Hall, the number of tourists from the UK alone was expected to decline by 20 percent, as a result of the threat of Kurdish terrorism in Turkey. This figure is quite significant, given that the tourism sector accounts for about 25 percent of Turkey's foreign currency earnings (cited in Westbury 2002).

In addition to regular attacks by PKK and others, Turkey has recently been subject to new terrorist incidents due to the political instability in the region. For example, looking forward, empirical findings presented in this paper justify the concerns that terrorism hurts tourism (Westbury 2002).

The findings developed here are of practical use for policymakers, helping them design effective domestic or region-wide strategies against terrorism. For example, in a speech delivered at the 56th Session of the United Nations General Assembly of the United Nations, New York on 12 November 2001, His Excellency the former president Moi made some remarks in which he equated poverty and the problem of terrorism with the political instability in the region:

The biggest challenge facing the African continent today is the increasing level of poverty. Poverty has become an obstacle, a roadblock to every effort we are making at improving the overall welfare of our people. 
Poverty is a fertile breeding ground for conflict and instability and even terrorism. It is therefore regrettable that very little progress, if any has been made since the world summit on social development in Copenhagen in 1995. I remind you that the main outcome of that summit was the resolve to eradicate poverty as an obstacle to human development. ${ }^{10}$

And although US President George W. Bush suggested there is no link between poverty and terrorism - in other words, poverty does not, by itself, prompt individuals to commit or be affected by terrorist acts research has suggested that it does so to a high magnitude. According to the head of the World Trade Organisation (WTO), Michael Moore, 'Poverty in all its forms is the greatest single threat to peace, security, democracy, human rights and the environment'.11

It is a mistake to disassociate the realities of hunger, poverty, and terrorism; they are inter-related, and any one of these may be the cause of the other two. The world does not need to tolerate despots, or war against entire populations in order to get rid of the one. Hundreds of thousands of lives are lost this way. The United Nations should use its authority to seek indictment by way of international criminal tribunals.

Acts of terrorism can have an extremely negative impact on a country's tourism, with ripple effects in several sectors of the economy. Tourism from an economic perspective has made a significant contribution to Kenya's Gross National Product (GNP). ${ }^{12}$ When terrorists strike or target the country, a lot of things will go wrong alongside tourism. Tourism employs many people in the hotels and entertainment sector and is also a source of earning from agricultural products as well as artifacts. When this happens it seriously disrupts tranquillity within the sector and economic decline follows immediately.

Tourism is an indicator for economic stability and when the country attracts more tourists, it helps in building confidence in the people, locally and internationally, that economically things are looking up. This will be very useful to local and international investors in various sectors of the economy. Acts of terrorism can lead to serious declines in the number of tourists coming into the country, thus denying the country much-needed foreign exchange. This will essentially deal a severe blow to wealth creation in the country. Tourism also has a major impact on the micro-economic environment.

The bombing of the twin towers in New York on September 11 , 2001 , caused a collapse in world tourism that also affected Kenya. Arrival 
figures have gone down since September 11 and Kenya is now about 12 percent down as compared to 2001. Nairobi arrivals have dropped more than Mombasa and there is a need to concentrate on boosting tourist arrivals into Nairobi. The strike on the American embassy in Nairobi in 1998 and the one that occurred in November 2002 on a Mombasa hotel frequented by Israelis seriously undermined gains made before. The gains and confidence painstakingly made over years were practically shattered as tourists started shying away from Kenya. Terrorism scares tourists into preferring other destinations where they will feel safe. ${ }^{13}$

\section{Conclusion}

For Kenya, African renaissance is, to begin with, a solution to the problem of security. Africa, as it were, is not insulated from its history and the global dynamics that have shaped its destiny in the past and in contemporary times. In this regard, the dialectics of imperialism and struggles for national liberation need to be seen as providing the context within which this rebirth is to take place. Internal security problems such as poverty, corruption, and crime viewed in their historical perspectives, should be addressed.

Far from being bogged down with problems of economic backwardness, political repression and external dependence, the renaissance in Africa is to be a product of the conscious will of social forces determined to bring positive changes to the lives of the African people. Systems of government that are autocratic and unresponsive to the needs of the people are to be replaced by those that are democratic and sensitive to political rights as well as people's basic needs. Instead of using public resources to satisfy the personal and selfish interests of power elites, systems that ensure good economic governance where public resources are used for the public good are to be preferred. A participant citizenry in the affairs of a modern republican government is to be encouraged as opposed to docile and oppressed subjects.

Although Kenya is seen to have achieved these desirable goals with the 2002 General Elections, hopes are fast seeping away - with provision of so-called 'democracy in abundance', the country seems to be losing its fabric, and the government's inability to handle a weak coalition means that the country is opening itself to further external attacks and the perpetuation of corruption. The 'democracy in abundance' which seeks not to discriminate in the screening of Somali and other immigrants into Kenya is a case to this point. 


\section{Recommendations}

In order to minimize the problem of security in the region so as to pave way for the renaissance in Kenya I suggest certain remedial actions:

- Nurture environments in which root causes of conflicts can be adequately addressed and durable stability established.

- Pursue negotiated solutions to conflicts so as to ensure their peaceful resolution, to promote a culture of peace, and to encourage education and awareness-raising programmes on the problem of illicit small arms, involving all sectors of society.

- Seek effective controls of arms transfers by suppliers outside the region, including measures against transfers of surplus arms to prevent the problem of illicit small arms.

- Call on states to strengthen sub-regional co-operation among police, intelligence, customs and border control officials in combating the illicit circulation and trafficking in small arms and light weapons and suppressing criminal activities relating to the use of these weapons.

- Invite the regional governments' cooperation with the AU and other regional and international organisations to assist countries of the region to carry out a detailed study on the problem of illicit arms within the region and to draw up appropriate programmes for the collection and destruction of illicit small arms and light weapons.

\section{Notes}

1. People [Nairobi], 5 December 2000, cited in Norwegian Refugee Council, 2002: 13.

2. Musambayi, pp. 260-30.

3. See for example in www.profileafrica.com.

4. Ibid.

5. See Buzan, Barry, O. Waever and J. de Wilde, Security: A New Framework For Analysis, London, Lynne Rienner Publishers, 1998; Booth, K. 'Strategy and Emancipation', Review of International Studies, 1991, Vol. 17, No. 4, pp. 313 326. and Graham, David T. and Nana Poku, Migration, Globalization and Human Security, New York Routledge, 2000.

6. Ullman, 1983, p. 133

7. Mombasa, on the Kenyan coast, is an important port of entry for goods that are transported across Kenya by rail or truck to Uganda, Rwanda, Burundi and eastern Democratic Republic of the Congo (DRC), all of which have been sites of large-scale armed violence in recent years. These areas thus constitute an economic hinterland of sorts inside a transnational regional trade area.

8. www.itdg.org, ITDG East Africa PEACE bulletin - Issue two, August 2003 peace-building.htm 
9. The Costs of Terrorism and the Benefits of Cooperating to Combat Terrorism', Paper presented by Dr Geoff Raby, Deputy Secretary, Department of Foreign Affairs and Trade to APEC Senior Officials Meeting, Chiang Rai, 21 February 2003 and submitted by Australia to the Secure Trade in the APEC Region (STAR) Conference, 24 Feb 2003. Economic Analytical Unit.

10. Daniel T. Arap Moi, speech delivered in the 56th Session of the United Nations General Assembly Of the United Nations, New York on 12 November, 2001.

11. Michael Moore, A Speech delivered at the International Development Summit in Mexico, 2002. Cited in BBC online magazine.

12. Professor Enos Njeru, Co-ordinator Social Sector of the Institute for Social Analysis Policy and Analysis Research (IPAR).in The East African Standard, 30/ $11 / 02$.

13. Ibid, p. 19, see also, The Kenya Times, 2/3/03, p. 7.

\section{Bibliography}

Adams, W., C, 1984, 'Opinion and Foreign Policy’, Foreign Service Journal, Vol. 6, May.

Adelman, H. and A. Suhrke, (eds.) 1999, The Path of a Genocide: The Rwandan Crisis from Uganda to Zaire, New Brunswick: Transaction Publishers.

Africa Confidential, 9 November 2001.

African Rights, 1995, Rwanda: Death, Despair and Defiance, London: African Rights.

Ablorh-Odjidja, E., 'Terrorism in Kenya: The Unholy Alliance of Silence, Religion and Ignorance', December 2, 2002, Online, www.profileafrica.com.

Ayakub, C., 'A Time for a New Beginning', A speech delivered at the Annual General Meeting of the freedom of expression institute, Johannesburg, 199

Baldwin, D.A, 1997, 'The Concept of Security', Review of International Studies, Vol. 23. No.1. pp. 5-26.

Apollos, F., (n.d. [2001]), 'Ethnicity, Violence and Democracy', Kenya: Centre for Conflict Resolution.

Bertrand, J., 1994, 'Une Èmeute sur la côte kényane', Afrique Contemporaine, no. 170, pp. 20-36.

Booth, K., 1991, 'Strategy and Emancipation', International Studies, Vol. 17. No. 4. pp. 313-326.

Brown, S., 2001, 'Authoritarian Leaders and Multiparty Elections in Africa: How Foreign Donors Help to Keep Kenya's Daniel Arap Moi in Power', Third World Quarterly, vol. 22, no. 5, pp. 725-39.

Brown, S., 2003a, 'Quiet Diplomacy and Recurring "Ethnic Clashes” in Kenya', in Chandra Lekha Sriram and Karin Wermester (eds.), From Promise to Practice: Strengthening UN Capacities for the Prevention of Violent Conflict, Boulder: Lynne Rienner, pp. 69-100.

Brown, S., 2003b, 'Deteriorating Human Security in Kenya: Domestic, Regional and Global Dimensions', in J. Andrew Grant and Fredrik Söderbaum (eds.), Regionalism in Africa, Aldershot: Ashgate. 
Buzan, B., Waever O, and de Wilde, J., 1998, Security: A New Framework For Analysis, London, Lynne Rienner Publishers.

Callamard, A., 1999, 'French Policy in Rwanda', in Adleman and Suhrke, op cit. pp. 157-83.

Daily Nation/Sunday Nation, Nairobi, various issues.

Destexhe, A., 1995, Rwanda and Genocide in the 21st Century, New York: New York University Press.

Drakos, Konstantinos and Kutan, Ali M., 2001, The Economic Effects of Terrorism, Zentrum für Europäische Integrationsforschung/Center for European Integration Studies, Rheinische Friedrich-Wilhelms-Universität Bonn.

East African, Nairobi, various issues.

Gnamo, A.H, 1999, 'The Rwandan Genocide and the Collapse of Mobutu's Kleptocracy’, in Adelman and Suhrke, op cit., pp. 321-49.

Goodwin-Gill, G., 1999, 'Refugees and Security - Editorial', International Journal of Refugee Law, 1 1 (1): 1-5.

Graham, D.T. and Poku, N., 2000, Migration, Globalization and Human Security, New York, Routledge.

Haugerud, A., 1995, The Culture of Politics in Modern Kenya, New York: Cambridge University Press

Halvorsen, K., 1999, 'Protection and Humanitarian Assistance in the Refugee Camps in Zaire: The Problem of Security', in Adelman and Suhrke, op cit. pp. 307-20.

Human Rights Watch/Arms Project, 1995, Rwanda/Zaire. Rearming with Impunity. International Support for the Perpetrators of the Rwandan Genocide, Washington DC.

Human Rights Watch, 2002, Playing with Fire: Weapons Proliferation, Political Violence, and Human Rights in Kenya, New York, Washington, London and Brussels, Human Rights Watch.

Ikins, C.G., 2001, Country Director for West Africa. United States Department of Defence. Interview with Richard J. Norton, Newport: Rhode Island, 25 January.

Jones, B. D., 1999, 'The Arusha Peace Process', in Adleman and Suhrke, op cit., pp.131-56.

Kagwanja, M., 1998, Killing the Vote: State Sponsored Violence and Flawed Elections in Kenya, Nairobi, Kenya Human Rights Commission.

Kagwanja, M., 2001, Raiding Democracy: The Slaughter of the Marakwet in Kerio Valley, Nairobi: Kenya Human Rights Commission.

Kagwanja, M., 2003, 'Facing Mount Kenya or Facing Mecca? The Mungiki, Ethnic Violence and the Politics of the Moi Succession in Kenya', African Affairs, vol. 102, no. 406, pp. 25-49.

Katzenstein, P., 1998, 'Regional Orders: Security in Europe and Asia', Paper presented at the 39th Annual International Studies Association Convention, Minneapolis, MN, March 17-21.

Keane, F., 1995, Season of Blood: A Rwandan Journey, New York: Viking.

Keating, M. and J. Loughlin (eds.), 1997, The Political Economy of Regionalism, London: Frank Cass. 
Kenya Human Rights Commission, 2000, The Forgotten People Revisited: Human Rights Abuses in Marsabit and Moyale Districts, Nairobi: KHRC.

Kenya Times, 27/01/03

Kenya Times, 8/7/03

Kuperman, A. F., 2002, 'Rwanda in Retrospect: A Hard Look At Intervention', Foreign Affairs, Vol. 79, January/February. pp.94-1 18.

Laegreid, T., 1999, 'UN Peacekeeping in Rwanda', in Adelman and Suhrke, op cit., pp. 231-51.

Lake, A., 1999, Interview with Richard J. Norton, 18 October.

Leach, A., 1997, 'Land Reform and Socioeconomic Change in Kenya', East African Journal of Peace and Human Rights, vol. 4, no. 1, pp. 41-69.

McNamara, D., 1998, 'Statement Before the House Committee on International Relations. Sub-Committee on International Operations and Human Rights. Hearing on "Rwanda: Genocide and the Continuing Cycle of Violence", 5 May.

Mills, K., 1998, 'United Nations Intervention in Refugee Crises after the Cold War', International Politics, 35, December, pp.391-424.

Miskel, J.F. and R.J. Norton, 1996, 'Going to Goma: The Rwanda Deployment', in National Security Volume II: Case Studies in US Contingency Operations,' Newport, Naval War College Press, pp.200-243.

Muggah, R. and E. Berman, 2001, Humanitarianism Under Threat: The Humanitarian Impact of Small Arms and Light Weapons, Special Report No. 1, Geneva, Small Arms Survey.

Murunga, G.R., 'Urban Violence in Kenya's Transition to Pluralist Politics 19821992', Africa Development, 1999, Vol. XXIV, No. $1 \& 2$.

Musambayi, K., 1998, '0,43\%4 au nord de l'Èquateur : une souveraineté à l'abandon', Politique Africaine, no. 70, pp. 22-31.

Okoth Kenya, Kenneth, 2003, 'What Role for Diaspora in Development?', Migration Policy Institute, August.

Olukoshi, A., 1998, 'Economic crisis, Multipartyism, and Opposition Politics in Contemporary Africa', in A. Olukoshi (ed.), The Politics of Opposition in Contemporary Africa, Stockholm: Gotab.

Prunier, G., 1997, 'The Geopolitical Situation in the Great Lakes Area in Light of the Kivu Crisis', WRITENET Country Papers. UNHCR. Online: http:// www.unhcr.ch/refworld/country/writenet/wridrc.htm.

Prunier,G., 1999, 'Opération Turquoise: A Humanitarian Escape from a Political Dead End', in Adelman and Suhrke, op cit., pp. 281-305.

Reed, W. C., 1998, 'Guerrillas in the Midst: The Former Government of Rwanda \& the Alliance of Democratic Forces for the Liberation of Congo-Zaire in Eastern Zaire', in Christopher Clapham. (ed.) 1998, African Guerrillas, Bloomington, IN: Indiana University Press, pp. 145-50.

Schulz, M., Söderbaum, F. and Öjendal, J., 2001, 'Introduction: A Framework for Understanding Regionalization’, in Michael Schulz, Fredrik Söderbaum and J. Öjendal (eds.), Regionalization in a Globalizing World: A Comparative Perspective on Forms, Actors and Processes, London and New York: Zed Books, pp. 1-21. 
Schuster, L. and J. Solomos Jr., 1999, 'The Politics of Refuge and Asylum Policies in Britain: Historical Patterns and Contemporary Realities', in A. Bloch and C. Levy (eds.) Refugees, Citizenship and Social Policy in Europe, London: Palgrave.

Suhrke, A., 1999, 'Dilemmas of Protection: The Log of the Kigali Battalion', in Adelman and Suhrke, op cit., pp. 253-80.

Tadesse, Medhane, 2001, 'Islamic Fundamentalism in Somalia: Its nature and implications', (WIC)04/10/0104, October, www.somaliawatch.org.

Ullman, Richard, 1983, 'Redefining Security', International Security, 8:1 , pp. 129153.

Westbury, Brian S., 2002, 'Economic Cost of Terrorism', International Information Programs Electronic Journal, September 11. 
